\title{
Photocatalytic decomposition of perfluorooctanoic acid in pure water and wastewater by needle-like nanostructured gallium oxide
}

\author{
Tian Shao, Pengyi Zhang *, Zhenmin Li, Ling Jin \\ State Key Joint Laboratory of Environment Simulation and Pollution Control, School of Environment, Tsinghua University, Beijing 100084, China
}

\section{A R T I C L E I N F O}

Article history:

Received 31 March 2013

Accepted 6 May 2013

Published 20 August 2013

Keywords:

Nanomaterial

Gallium oxide

Perfluorooctanoic acid

Photocatalysis

Vacuum ultraviolet

\begin{abstract}
A B S T R A C T
Nanostructured $\beta-\mathrm{Ga}_{2} \mathrm{O}_{3}$ with a needle-like structure was synthesized by a polyvinyl alcohol (PVA)assisted hydrothermal method and subsequent heat treatment. It has a high specific surface area $\left(25.95 \mathrm{~m}^{2} / \mathrm{g}\right)$ and large number of nanopores $(4-25 \mathrm{~nm})$, and it exhibited good photocatalytic activity for perfluorooctanoic acid (PFOA) decomposition in pure water unde UV irradiation $(\lambda=254$ $\mathrm{nm})$. PFOA had a half-life of $18.2 \mathrm{~min}$, and the first order rate constant $\left(2.28 \mathrm{~h}^{-1}\right)$ for PFOA decomposition with the needle-like $\beta-\mathrm{Ga}_{2} \mathrm{O}_{3}$ was 7.5 and 16.8 times higher, respectively, than with commercial $\mathrm{Ga}_{2} \mathrm{O}_{3}$ and $\mathrm{TiO}_{2}$ (P25). In addition, in combination with vacuum UV (VUV) irradiation $(\lambda=185$ $\mathrm{nm}$ ), the needle-like $\beta-\mathrm{Ga}_{2} \mathrm{O}_{3}$ showed high activity for the removal of trace PFOA in both pure water and wastewater, with first order rate constants of 4.03 and $3.51 \mathrm{~h}^{-1}$, respectively. The adverse effect that coexisting natural organic matters in wastewater have on the decomposition of PFOA was mostly eliminated with VUV irradiation, and the energy consumption in this method was much less than the values reported for other methods in the literature.
\end{abstract}

(C) 2013, Dalian Institute of Chemical Physics, Chinese Academy of Sciences. Published by Elsevier B.V. All rights reserved.

\section{Introduction}

Perfluorooctanoic acid (PFOA, $\mathrm{C}_{7} \mathrm{~F}_{15} \mathrm{COOH}$ ) is an emerging persistent organic pollutant that belongs to a class of fully fluorinated hydrocarbons known as perfluorocarboxylic acids (PFCAs, $\mathrm{C}_{n} \mathrm{~F}_{2 n+1} \mathrm{COOH}$ ). Due to the strong carbon-fluorine bonds, PFOA is extraordinarily stable thermally and chemically. As a result, it is widely used as a surfactant and fire retardant in various industrial fields. Owing to its environmental persistence and bioaccumulation, it has been extensively reported that PFOA is now globally distributed in world waters, animals and humans [1-5]. Toxicological studies have demonstrated that exposure to PFOA can lead to developmental and reproductive toxicity problems, liver damage, and possibly cancer [6-8]. The potential hazard that PFOA poses to human health and wild life has increasingly attracted worldwide concerns.

Due to its wide application in consumer products and industrial manufacture [9], PFOA and its precursors have been widely released into nature, particularly from wastewater treatment plants [10,11]. PFOA resists most conventional treatment processes including biological degradation, and oxidation and reduction methods [12]. Recent studies showed that special techniques such as thermolysis [13], ultrasonication $[14,15]$, and photochemistry approaches [16-19] can decompose PFOA in aqueous solution, but these also have serious drawbacks, such as severe operation conditions and high energy consumption. Among the potential methods for PFOA decomposition, heterogeneous photocatalysis is attractive for its low energy consumption and high efficiency for completely degrading various kinds of organic contaminants. However,

\footnotetext{
*Corresponding author. Tel: +86-10-62796840; Fax: +86-10-62797760; E-mail: zpy@tsinghua.edu.cn This work was supported by the National Natural Science Foundation of China $(21177071,21221004)$ and the National Basic Research Program of China (973 Program, 2013CB632403). 
$\mathrm{TiO}_{2}$, which is the most widely investigated photocatalyst, showed very low activity for PFOA decomposition under mild conditions [20]. Fortunately, our previous research has shown that other semiconductors, such as $\beta-\mathrm{Ga}_{2} \mathrm{O}_{3}$ and $\mathrm{In}_{2} \mathrm{O}_{3}$, can decompose PFOA, and their activity can be further enhanced by a proper synthesis strategy to give nanostructure materials [21-23].

Here, we synthesized $\mathrm{Ga}_{2} \mathrm{O}_{3}$ with a needle-like nanostructure. The needle-like $\beta-\mathrm{Ga}_{2} \mathrm{O}_{3}$ was prepared by a polyvinyl alcohol (PVA)-assisted hydrothermal method followed by calcination. The prepared materials exhibited remarkable photocatalytic activity for PFOA decomposition in pure water as well as municipal wastewater.

\section{Experimental}

\subsection{Preparation of needle-like $\mathrm{Ga}_{2} \mathrm{O}_{3}$}

All reagents were analytical grade and were used as received. $\mathrm{Ga}_{2} \mathrm{O}_{3}$ was synthesized by a hydrothermal method followed by calcination. In a typical procedure, $2 \mathrm{~g}(5 \mathrm{mmol})$ of $\mathrm{Ga}\left(\mathrm{NO}_{3}\right)_{3} \cdot x \mathrm{H}_{2} \mathrm{O}$ and $0.1173 \mathrm{~g}$ of PVA $\left(M_{\mathrm{W}}=22000\right)$ were dissolved in $20 \mathrm{ml}$ pure water, and the $\mathrm{pH}$ was adjusted to 6.4 using $\mathrm{NaOH}$ solution. After heating at $90{ }^{\circ} \mathrm{C}$ for $10 \mathrm{~min}$, the mixture was transferred into a $25 \mathrm{ml}$ Teflon-lined stainless steel autoclave and maintained at $200^{\circ} \mathrm{C}$ for $8 \mathrm{~h}$. After the autoclave was naturally cooled to room temperature, the white precipitate (precursor of $\mathrm{Ga}_{2} \mathrm{O}_{3}$ ) was collected by centrifugation and washed with ultra-pure water and ethanol three times. Then the white precipitate was dried at room temperature for $12 \mathrm{~h} . \mathrm{Ga}_{2} \mathrm{O}_{3}$ powder was obtained from the precursor by calcination at $700{ }^{\circ} \mathrm{C}$ for $2 \mathrm{~h}$ in nitrogen (heating rate $1^{\circ} \mathrm{C} / \mathrm{min}$ ).

\subsection{Characterization}

X-ray powder diffraction (XRD) patterns were obtained on a PANalytical X'Pert pro diffractometer at $40 \mathrm{kV}$ voltage and 200 $\mathrm{mA}$ current. The morphologies of the samples were observed using a Hitachi S-5500 ultra-high resolution field emission scanning electron microscope (FESEM) performed at an accelerating voltage of $5.0 \mathrm{kV}$. Transmission electron microscopy (TEM) images were taken on a JEOL JEM 2010F microscope at an accelerating voltage of $200 \mathrm{kV}$. The diffuse reflectance absorption spectra (DRS) of the samples were recorded by a Shimadzu UV2700 UV-Vis spectrophotometer. Nitrogen adsorption isotherms were obtained on a Quantachrome Autosorb-1MP instrument.

\subsection{Photocatalytic decomposition of PFOA}

The photocatalytic decomposition of PFOA was conducted in a tubular quartz reactor under ultraviolet irradiation. Two kinds of low pressure mercury lamps (14 W, Cnlight Co. Ltd., China) with the same electric power, appearance, and size were alternatively used. One only emits $254 \mathrm{~nm}$ UV light (hereafter referred as UV), and the other emits $254 \mathrm{~nm} \mathrm{UV}$ and $185 \mathrm{~nm}$ vacuum UV light (hereafter referred as VUV). The UV or VUV lamp was placed in the center of the reactor with a two-layer quartz tube protection. In a typical experiment, $150 \mathrm{ml}$ of PFOA aqueous solution $\left(C_{0} \approx 500 \mu \mathrm{g} / \mathrm{L}\right)$ was prepared by diluting the stock solution in a beaker. Photocatalyst $(0.075 \mathrm{~g}, 0.5 \mathrm{~g} / \mathrm{L})$ was added in the PFOA solution and stirred for $1 \mathrm{~h}$. Then, the suspension was added into the reactor, and oxygen gas was continuously bubbled in at a flow rate of $60 \mathrm{ml} / \mathrm{min}$ for $10 \mathrm{~min}$ before the lamp was turned on. The reaction temperature was maintained at $25{ }^{\circ} \mathrm{C}$ with a cooling water jacket around the reactor. At regular time intervals, aliquots of solution were taken and filtered with $0.22 \mu \mathrm{m}$ ultrafiltration membrane to remove the photocatalyst powder. The filtered samples were kept at $4{ }^{\circ} \mathrm{C}$ for analysis.

The concentrations of PFOA and its decomposition products were measured with a Waters Acquity UPLC system coupled with a Waters Micromass Quattro Premier tandem quadrupole mass spectrometer. The multiple reaction monitoring mode (MRM) was used for the quantitative analysis of PFOA and other shorter chain PFCAs. The separation column was a Waters Acquity UPLC BEH C 18 column (2.1 mm i.d. $\times 50 \mathrm{~mm}, 1.7 \mu \mathrm{m}$ particles), and the column temperature was set at $50{ }^{\circ} \mathrm{C}$. The concentration of fluoride ion $\left(\mathrm{F}^{-}\right)$was determined by an ICS-2000 Dionex ion chromatography. The sample was injected into an IonPac AS11-HC column (4 mm $\times 250 \mathrm{~mm})$ with an IonPac AG11-HC guard column (4 mm $\times 50 \mathrm{~mm})$. A mixture solution containing $3.2 \mathrm{mmol} / \mathrm{L} \mathrm{Na}_{2} \mathrm{CO}_{3}$ and $1 \mathrm{mmol} / \mathrm{L} \mathrm{NaHCO}_{3}$ was used as the mobile phase at a flow rate of $1.0 \mathrm{ml} / \mathrm{min}$.

\section{Results and discussion}

\subsection{Crystal phase of $\mathrm{Ga}_{2} \mathrm{O}_{3}$}

The XRD pattern of the final product synthesized by the PVA-assisted hydrothermal process and subsequent heat treatment is shown in Fig. 1. All the peaks can be indexed to $\beta-\mathrm{Ga}_{2} \mathrm{O}_{3}(a=12.2270, b=3.0389, c=5.8079$, JCPDS 41-1103) with no observation of other crystal phases. The peaks were sharp and narrow, indicating a high crystallinity for the samples.

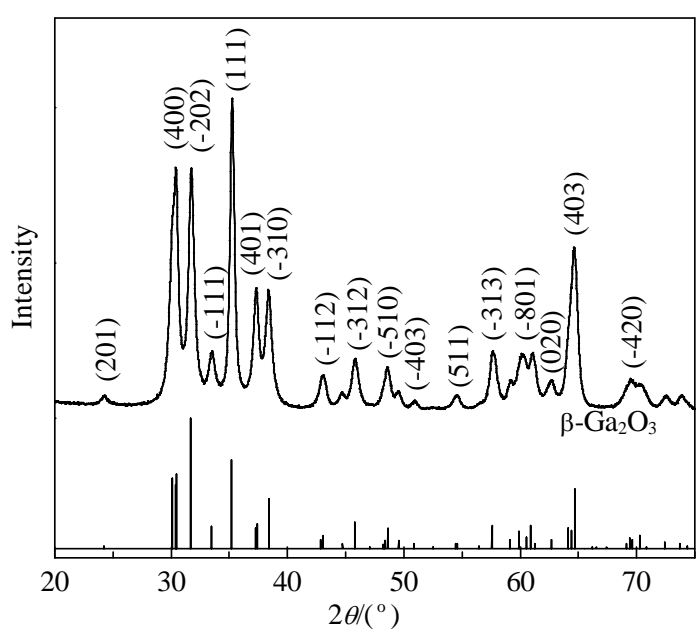

Fig. 1. XRD pattern of the $\mathrm{Ga}_{2} \mathrm{O}_{3}$ sample. 

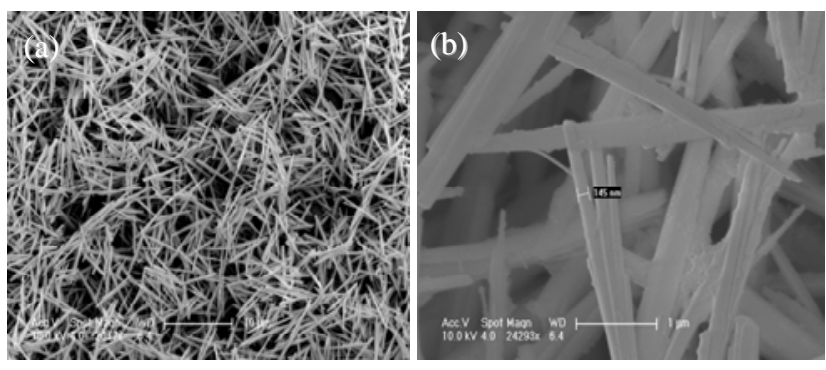

Fig. 2. Low (a) and high (b) magnification SEM images of the $\beta-\mathrm{Ga}_{2} \mathrm{O}_{3}$ nanostructure.

\subsection{Microstructure of $\mathrm{Ga}_{2} \mathrm{O}_{3}$}

Figure 2(a) and (b) are typical SEM images of the $\beta-\mathrm{Ga}_{2} \mathrm{O}_{3}$. The low magnification image (Fig. 2(a)) showed a needle-like morphology with a fairly uniform shape and size. Further observation with the high magnification SEM image (Fig. 2(b)) showed that individual needles have a length of 3-6 $\mu \mathrm{m}$ and a width of 100-200 $\mathrm{nm}$. The surfaces of the needles were relatively rough due to dehydration shrinkage during calcination.

The needle-like structure of the $\beta-\mathrm{Ga}_{2} \mathrm{O}_{3}$ was further confirmed with TEM (Fig. 3(a)), which also showed that the $\mathrm{Ga}_{2} \mathrm{O}_{3}$ particles were well dispersed without agglomeration and had widths of 100-200 nm. The inset in Fig. 3(a) shows the selected area electron diffraction (SAED) pattern of an individual nano-needle. The presence of obvious discrete spots revealed that it was single crystalline. A high magnification TEM image (Fig. 3(b)) of a nano-needle segment marked in the inset of Fig. 3(b) showed a clear lattice fringe with a lattice interplanar spacing of $0.152 \mathrm{~nm}$, which corresponds to the (020) crystal plane of $\beta-\mathrm{Ga}_{2} \mathrm{O}_{3}$. The lattice fringes revealed that the nano-needdles were elongated in the [020] direction.

\subsection{Specific surface area and pore size distribution of $\mathrm{Ga}_{2} \mathrm{O}_{3}$}

The $\mathrm{N}_{2}$ adsorption isotherm and pore size distribution of the needle-like $\mathrm{Ga}_{2} \mathrm{O}_{3}$ are shown in Fig. 4. The isotherm is type IV with a hysteresis loop, indicating that the sample has a mesoporous structure. The pore size distribution (inset in Fig. 4) obtained from the isotherm indicated the existence of a number of 2-4 $\mathrm{nm}$ pores and 6-25 $\mathrm{nm}$ pores. These pores were probably due to the stacking of nano-needles and dehydration shrinkage during calcination. These pores increased the surface
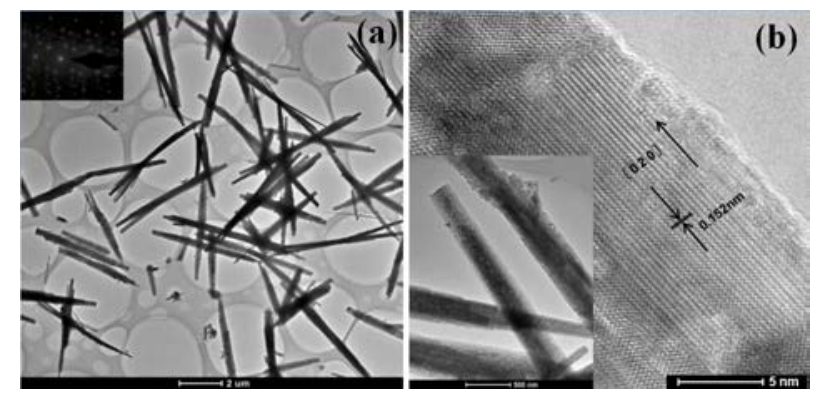

Fig. 3. (a) TEM image and corresponding SAED pattern (inset in right upper corner); (b) HRTEM image of the rectangle region (inset in the left bottom corner) of the needle-like $\mathrm{Ga}_{2} \mathrm{O}_{3}$.

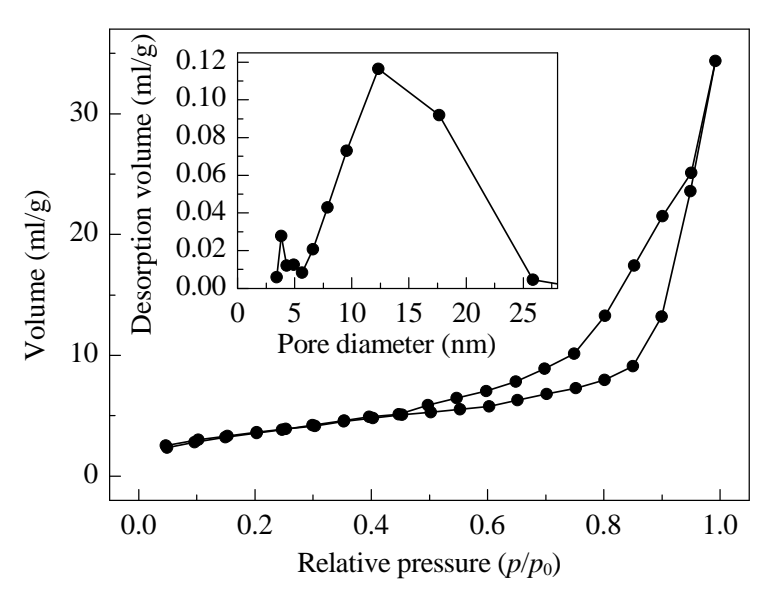

Fig. 4. $\mathrm{N}_{2}$ adsorption isotherm and pore size distribution (inset) of the needle-like $\mathrm{Ga}_{2} \mathrm{O}_{3}$.

area of the material. The BET specific surface area of the needle-like $\mathrm{Ga}_{2} \mathrm{O}_{3}$ was $25.95 \mathrm{~m}^{2} / \mathrm{g}$, while that of commercial $\mathrm{Ga}_{2} \mathrm{O}_{3}$ is $11.5 \mathrm{~m}^{2} / \mathrm{g}$.

\subsection{UV-Vis absorption spectrum of $\mathrm{Ga}_{2} \mathrm{O}_{3}$}

The UV-Vis absorption spectra of the needle-like $\mathrm{Ga}_{2} \mathrm{O}_{3}$ and a commercial $\mathrm{Ga}_{2} \mathrm{O}_{3}$ are shown in Fig. 5. Both samples had obvious absorption in the ultraviolet zone ranging from 200 to $380 \mathrm{~nm}$. The needle-like $\mathrm{Ga}_{2} \mathrm{O}_{3}$ showed a slight blue shift in comparison to the commercial $\mathrm{Ga}_{2} \mathrm{O}_{3}$, which may be due to the quantum confinement effect in the nano-sized material. From the plots used to estimate the band gap energy (inset in Fig. 5), the band gap energies for the needle-like $\mathrm{Ga}_{2} \mathrm{O}_{3}$ and commercial $\mathrm{Ga}_{2} \mathrm{O}_{3}$ were 4.68 and $4.57 \mathrm{eV}$, respectively.

\subsection{UV photocatalytic decomposition of PFOA in pure water}

A series of comparative experiments were carried out to investigate the photocatalytic activity of the needle-like $\mathrm{Ga}_{2} \mathrm{O}_{3}$, commercial $\mathrm{Ga}_{2} \mathrm{O}_{3}$, and $\mathrm{P} 25 \mathrm{TiO}_{2}$ for the decomposition of PFOA in pure water. The aqueous solution of PFOA (500 $\mu \mathrm{g} / \mathrm{L})$ was

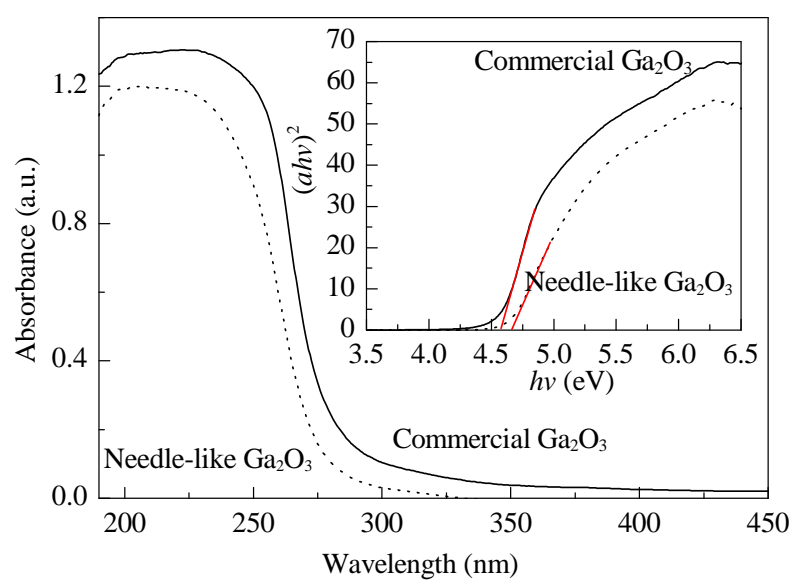

Fig. 5. UV-Vis absorption spectra of needle-like $\mathrm{Ga}_{2} \mathrm{O}_{3}$ and commercial $\mathrm{Ga}_{2} \mathrm{O}_{3}$, the inset showed the plots of $(a h v)^{2}$ versus the energy of light (hv). 


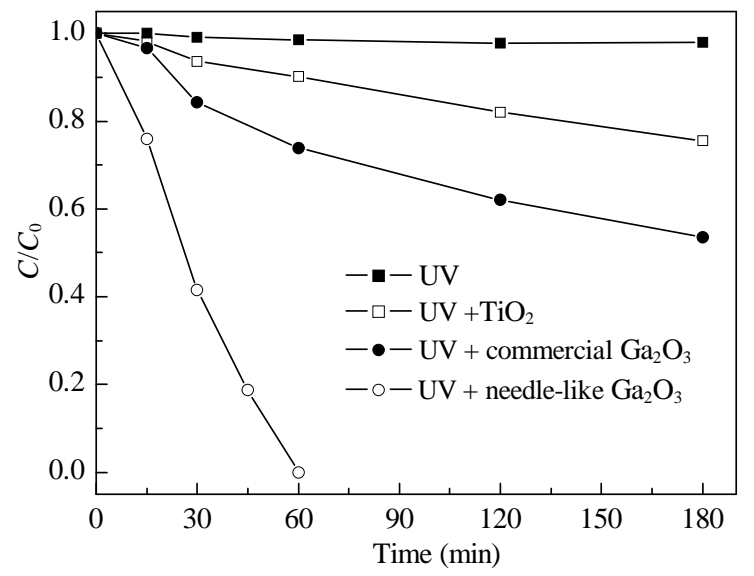

Fig. 6. PFOA decomposition versus time under UV irradiation in pure water by different photocatalysts.

irradiated with the $254 \mathrm{~nm}$ UV lamp. The initial $\mathrm{pH}$ value of the PFOA solution was about 4.8, which was not adjusted during the whole process. As shown in Fig. 6, after 3 h, 3.2\% PFOA was degraded by the direct photolysis of $254 \mathrm{~nm}$ UV light. PFOA decomposition by $\mathrm{P} 25 \mathrm{TiO}_{2}$ was also insignificant under this mild condition, and only $24 \%$ PFOA was decomposed in $3 \mathrm{~h}$. In the presence of the commercial $\mathrm{Ga}_{2} \mathrm{O}_{3}$, the decomposition of PFOA in $3 \mathrm{~h}$ was increased to $38 \%$. However, when the needle-like $\mathrm{Ga}_{2} \mathrm{O}_{3}$ was used as the photocatalyst, the decomposition rate of PFOA increased dramatically, and PFOA was completely decomposed within $1 \mathrm{~h}$. The PFOA decomposition under various conditions was fitted well with pseudo-first order kinetics. As shown in Table 1, the rate constant for the needle-like $\mathrm{Ga}_{2} \mathrm{O}_{3}$ was $2.28 \mathrm{~h}^{-1}$, which was 7.5 and 16.8 times higher than those of commercial $\mathrm{Ga}_{2} \mathrm{O}_{3}$ and $\mathrm{P} 25 \mathrm{TiO}_{2}$, respectively.

The excellent performance of the synthesized $\mathrm{Ga}_{2} \mathrm{O}_{3}$ for PFOA decomposition can be attributed to its unique bonding to PFOA, which is similar to that between $\mathrm{In}_{2} \mathrm{O}_{3}$ and PFOA. This is beneficial for PFOA decomposition by photogenerated holes of the photocatalyst under UV irradiation [23]. Thus, compared to $\mathrm{TiO}_{2}$, both the commercial and needle-like $\mathrm{Ga}_{2} \mathrm{O}_{3}$ exhibited better photocatalytic activity for PFOA decomposition. Meanwhile, the needle-like $\mathrm{Ga}_{2} \mathrm{O}_{3}$ showed remarkably higher photocatalytic activity in comparison to the commercial $\mathrm{Ga}_{2} \mathrm{O}_{3}$ because the larger surface area of the needle-like $\mathrm{Ga}_{2} \mathrm{O}_{3}$ provides more adsorption and reaction centers.

Besides the fluoride ion detected as the final product during PFOA decomposition, shorter chain $\mathrm{C}_{2}-\mathrm{C}_{7}$ PFCAs were also identified as major intermediate products by UPLC-MS/MS. The time change of the intermediates and fluoride ion concentrations during PFOA decomposition is given in Fig. 7. The amount of C7 PFCA, i.e., PFHpA, increased to a maximum in $30 \mathrm{~min}$ and

Table 1

Reaction rate constants and half-life times of PFOA under UV irradiation.

\begin{tabular}{llcc}
\hline Sample & $k / \mathrm{h}^{-1}$ & $R^{2}$ & $t_{1 / 2} / \mathrm{min}$ \\
\hline Needle-like $\mathrm{Ga}_{2} \mathrm{O}_{3}$ & 2.280 & 0.940 & 18.2 \\
Commercial $\mathrm{Ga}_{2} \mathrm{O}_{3}$ & 0.303 & 0.992 & 137.3 \\
$\mathrm{TiO}_{2}$ & 0.135 & 0.957 & 308.1 \\
\hline
\end{tabular}

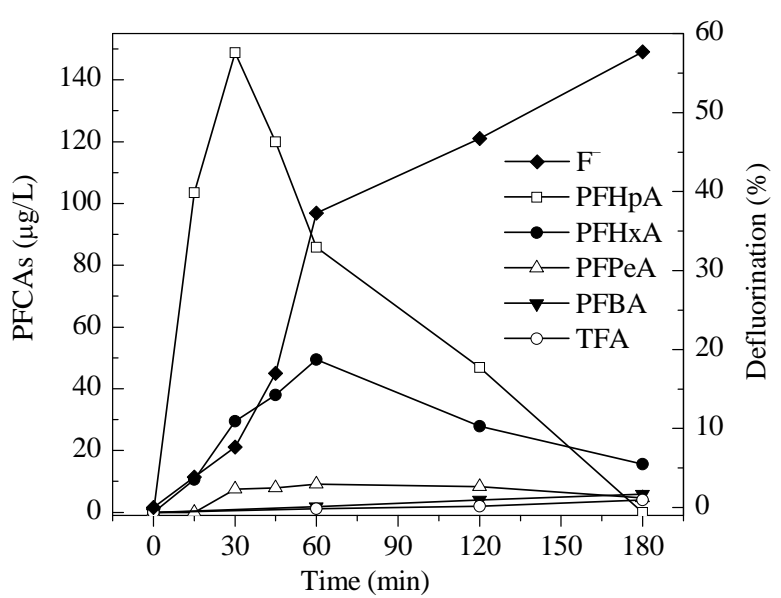

Fig. 7. Concentrations of short chain intermediates and fluoride ion produced during PFOA decomposition versus time under UV irradiation with needle-like $\mathrm{Ga}_{2} \mathrm{O}_{3}$.

then gradually decreased with reaction time. PFHxA followed a similar trend, except that the time at which it reached its maximum concentration was $60 \mathrm{~min}$. The concentrations of other shorter chain PFCAs were low and no more than $10 \mu \mathrm{g} / \mathrm{L}$, though they increased during the $3 \mathrm{~h}$ reaction. The shorter the carbon chain, the lower was its concentration. These characteristics strongly suggested the stepwise cleavage of the PFOA carbon chain during its photocatalytic decomposition [24]. Simultaneously, fluoride ions in the aqueous solution were detected, which increased with time. After $3 \mathrm{~h}$ reaction, the defluorination ratio reached that $58 \%$, which means $58 \%$ of organic fluorine had been transformed into inorganic fluorine in $3 \mathrm{~h}$.

\subsection{VUV photocatalytic decomposition of PFOA in pure water}

VUV $(\lambda<200 \mathrm{~nm})$, a kind of UV light with a short wavelength and high energy, can photodissociate water into a $\mathrm{H}$ atom and $\mathrm{HO} \bullet$ radical and directly photolyze organic pollutants [25]. The PFOA solution (500 $\mu \mathrm{g} / \mathrm{L})$ was irradiated with a 185 nm VUV lamp in the presence of the needle-like $\mathrm{Ga}_{2} \mathrm{O}_{3}$, commercial $\mathrm{Ga}_{2} \mathrm{O}_{3}$, and $\mathrm{P} 25 \mathrm{TiO}_{2}$. As shown in Fig. 8, by direct VUV

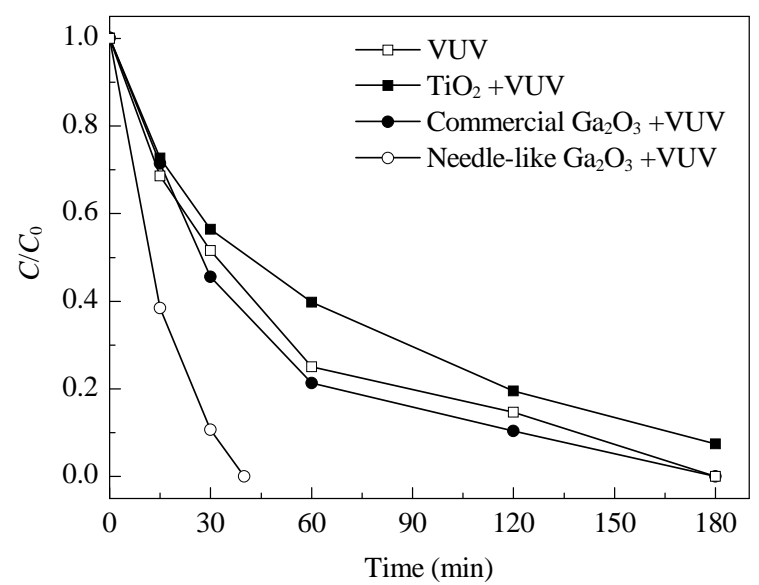

Fig. 8. PFOA decomposition under VUV irradiation in pure water with different photocatalysts. 
photolysis, PFOA was decomposed to less than the detection limit within $3 \mathrm{~h}$ of irradiation, indicating the ability of $185 \mathrm{~nm}$ VUV to directly decompose PFOA. When the commercial $\mathrm{Ga}_{2} \mathrm{O}_{3}$ was used together with VUV, no significant improvement occurred as compared with VUV photolysis. When $\mathrm{P} 25 \mathrm{TiO}_{2}$ was used together with VUV, the decomposition of PFOA was $92 \%$ in $3 \mathrm{~h}$, which was lower than that by direct photolysis. This was because $\mathrm{TiO}_{2}$ suspended in the solution absorbed and scattered VUV light, while the activity of $\mathrm{TiO}_{2}$ for PFOA decomposition is low. However, when the needle-like $\mathrm{Ga}_{2} \mathrm{O}_{3}$ was combined with VUV irradiation, the rate of PFOA decomposition was significantly enhanced, and PFOA completely decomposed within 40 min, with a half-time of $10.3 \mathrm{~min}$. The decomposition rate constant was $4.03 \mathrm{~h}^{-1}$, which was 1.77 times that under UV irradiation. The improved decomposition efficiency of PFOA under VUV light irradiation can be attributed to the ability of VUV to direct photolyze PFOA. The combination of VUV light and nanostructured needle-like $\mathrm{Ga}_{2} \mathrm{O}_{3}$ further significantly improved the decomposition efficiency for PFOA. The energy consumption of this method was $94.6 \mathrm{~kJ} / \mu \mathrm{mol}$, which is much lower than those of other methods. Among the reported methods to decompose trace PFOA in water, sonolysis has the shortest half-time, which is $15 \mathrm{~min}(\mathrm{PFOA}=200 \mathrm{nmol} / \mathrm{L})$, while its energy consumption is $1300 \mathrm{~kJ} / \mu \mathrm{mol}$ [12].

\subsection{Photocatalytic decomposition of PFOA in sewage}

To validate the feasibility of the needle-like $\mathrm{Ga}_{2} \mathrm{O}_{3}$ to decompose PFOA in actual wastewater, in which coexisting compounds may reduce decomposition efficiency, we investigated the decomposition of PFOA added into a secondary effluent from a municipal wastewater plant. The total organic carbon (TOC) concentration in the effluent was $18.9 \mathrm{mg} / \mathrm{L}$. Its $\mathrm{pH}$ value was adjusted to 4.8 with $\mathrm{HCl}$ in order to compare the decomposition of PFOA with that in pure water. The blank experiment, i.e. direct VUV photolysis, was carried out under the same condition without a photocatalyst. Figure 9 shows the time change of PFOA concentration in the wastewater degraded by the needle-like $\mathrm{Ga}_{2} \mathrm{O}_{3}$ under UV and VUV light. Under UV light, the decomposition of PFOA in the wastewater was obviously retarded. It took 160 min to completely degrade PFOA, which was

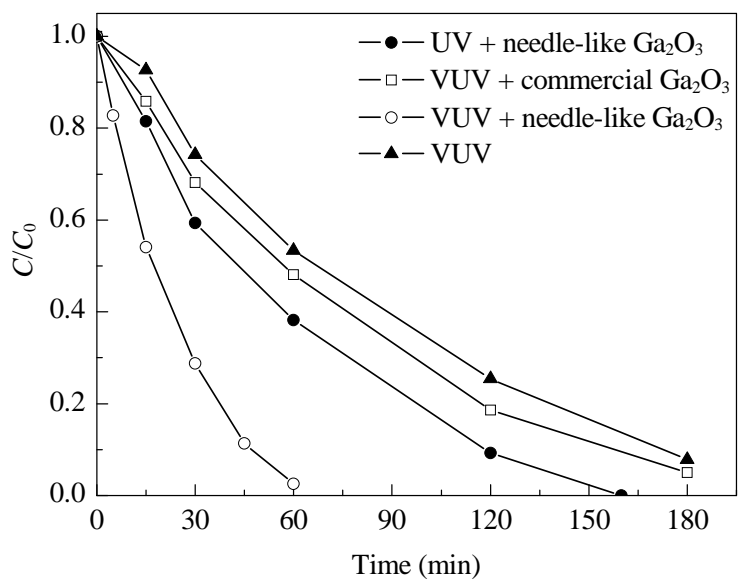

Fig. 9. PFOA decomposition in sewage water under different conditions. much longer than the time needed with pure water (60 min). The lower decomposition rate of PFOA in the secondary effluent can be attributed to the influence of coexisting organic matters, which competitively adsorb on the surface of $\mathrm{Ga}_{2} \mathrm{O}_{3}$. The direct photolysis rate of PFOA by VUV light was also reduced, and only $92 \%$ of the PFOA was decomposed after $3 \mathrm{~h}$ of irradiation. When VUV was combined with the commercial $\mathrm{Ga}_{2} \mathrm{O}_{3}$, the decomposition after $3 \mathrm{~h}$ was slightly increased to $95 \%$. When using the needle-like $\mathrm{Ga}_{2} \mathrm{O}_{3}$ as photocatalyst under VUV irradiation, PFOA was completely decomposed to less than the detection limit within $65 \mathrm{~min}$, which was a significant enhancement as compared with VUV photolysis and commercial $\mathrm{Ga}_{2} \mathrm{O}_{3} / \mathrm{VUV}$ photocatalysis. The high efficiency of the needle-like $\mathrm{Ga}_{2} \mathrm{O}_{3} /$ VUV system for PFOA removal from wastewater was not only due to VUV irradiation, which eliminated the adverse impact of coexisting organic matters, but it should also be attributed to the unique catalytic activity of the nanostructured $\mathrm{Ga}_{2} \mathrm{O}_{3}$ to decompose PFOA. The corresponding reaction rate constant was $3.51 \mathrm{~h}^{-1}$ (the half time was $11.8 \mathrm{~min}$ ), which is much higher than the values reported in the literature. For example, Li et al. [23] added ozone to decompose PFOA in wastewater (TOC $18.9 \mathrm{mg} / \mathrm{L}$, PFOA $30 \mathrm{mg} / \mathrm{L}$ ) using $\mathrm{In}_{2} \mathrm{O}_{3} / \mathrm{UV}$ photocatalysis and observed 80\% PFOA degraded after $4 \mathrm{~h}$. Giri et al. [26] degraded PFOA in wastewater (NPOC $3.5 \mathrm{mg} / \mathrm{L}$, PFOA $2.43 \mu \mathrm{mol} / \mathrm{L}$ ) by VUV photolysis, but only 34\% PFOA was degraded after $4 \mathrm{~h}$. Moreover, the energy consumption to decompose PFOA in wastewater by the needle-like $\mathrm{Ga}_{2} \mathrm{O}_{3} / \mathrm{VUV}$ was $108.6 \mathrm{~kJ} / \mu \mathrm{mol}$, which is much less than the values for other methods reported in the literature. For instance, Cheng et al. [27] tested the sonochemical degradation rate of PFOA in groundwater (TOC $20 \mathrm{mg} / \mathrm{L}$, PFOA $100 \mu \mathrm{g} / \mathrm{L}$ ) and reported that the reaction rate constant was $1.26 \mathrm{~h}^{-1}$ and the energy consumption was as high as $4099 \mathrm{~kJ} / \mu \mathrm{mol}$.

\section{Conclusions}

A needle-like nanostructured $\beta-\mathrm{Ga}_{2} \mathrm{O}_{3}$ was synthesized by a hydrothermal method followed by calcination. The needle-like $\mathrm{Ga}_{2} \mathrm{O}_{3}$ has a specific surface area of $25.95 \mathrm{~m}^{2} / \mathrm{g}$ and a large number of pores (4-25 nm). The needle-like $\mathrm{Ga}_{2} \mathrm{O}_{3}$ exhibited remarkable photocatalytic activity for PFOA decomposition. Under $254 \mathrm{~nm}$ UV light, the half-life of PFOA decomposition by the needle-like $\beta-\mathrm{Ga}_{2} \mathrm{O}_{3}$ in pure water was $18.2 \mathrm{~min}$, and the corresponding first order rate constant was 7.5 and 16.8 times higher than those of commercial $\mathrm{Ga}_{2} \mathrm{O}_{3}$ and $\mathrm{P} 25 \mathrm{TiO}_{2}$, respectively. When the needle-like $\mathrm{Ga}_{2} \mathrm{O}_{3}$ was used as the photocatalyst under UV irradiation to degrade PFOA in wastewater, coexisting compounds in the wastewater significantly inhibited the photocatalytic decomposition of PFOA. However, in combination with VUV light, the needle-like $\mathrm{Ga}_{2} \mathrm{O}_{3}$ efficiently decomposed PFOA in wastewater, and the energy consumption of this method was much less than those of other methods reported in the literature.

\section{References}

[1] Benskin J P, Yeung L W Y, Yamashita N, Taniyasu S, Lam P K S, 


\title{
Graphical Abstract
}

Chin. J. Catal., 2013, 34: 1551-1559 doi: 10.1016/S1872-2067(12)60612-3

Photocatalytic decomposition of perfluorooctanoic acid in pure water and wastewater by needle-like nanostructured gallium oxide

Tian Shao, Pengyi Zhang*, Zhenmin Li, Ling Jin

Tsinghua University
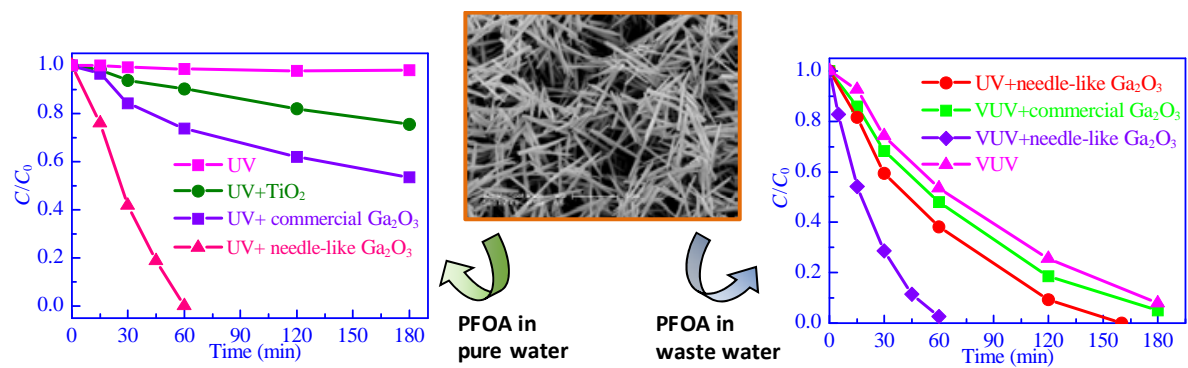

In combination with $185 \mathrm{~nm}$ vacuum UV irradiation, needle-like $\mathrm{Ga}_{2} \mathrm{O}_{3}$ showed high efficiency for the removal of trace perfluorooctanoic acid (PFOA) in wastewater where the decomposition of PFOA by other catalysts is usually inhibited by coexisting natural organic matters.

Martin J W. Environ Sci Technol, 2010, 44: 9049

[2] Zhang T, Wu Q, Sun H W, Zhang X Z, Yun S H, Kannan K. Environ Sci Technol, 2010, 44: 4341

[3] Shin H M, Vieira V M, Ryan P B, Detwiler R, Sanders B, Steenland K, Bartell S M. Environ Sci Technol, 2011, 45: 1435

[4] Takagi S, Adachi F, Miyano K, Koizumi Y, Tanaka H, Mimura M, Watanabe I, Tanabe S, Kannan K. Chemosphere, 2008, 72: 1409

[5] Wania F. Environ Sci Technol, 2007, 41: 4529

[6] Zhao G P, Wang J, Wang X F, Chen S P, Zhao Y, Gu F, Xu A, Wu L J. Environ Sci Technol, 2011, 45: 1638

[7] Yang J H. Chemosphere, 2010, 81: 548

[8] Nolan L A, Nolan J M, Shofer F S, Rodway N V, Emmett E A. Reprod Toxicol, 2009, 27: 231

[9] Prevedouros K, Cousins I T, Buck R C, Korzeniowski S H. Environ Sci Technol, 2006, 40: 32

[10] Schultz M M, Higgins C P, Huset C A, Luthy R G, Barofsky D F, Field J A. Environ Sci Technol, 2006, 40: 7350

[11] Sinclair E, Kannan K. Environ Sci Technol, 2006, 40: 1408

[12] Vecitis C D, Park H, Cheng J, Mader B T, Hoffmann M R. Front Environ Sci Engin China, 2009, 3: 129

[13] Krusic P J, Marchione A A, Roe D C. J Fluorine Chem, 2005, 126: 1510
[14] Cheng J, Vecitis C D, Park H, Mader B T, Hoffmann M R. Environ Sci Technol, 2010, 44: 445

[15] Moriwaki H, Takagi Y, Tanaka M, Tsuruho K, Okitsu K, Maeda Y. Environ Sci Technol, 2005, 39: 3388

[16] Hori H, Hayakawa E, Einaga H, Kutsuna S, Koike K, Ibusuki T, Kiatagawa H, Arakawa R. Environ Sci Technol, 2004, 38: 6118

[17] Wang Y, Zhang P Y, Pan G, Chen H. J Hazard Mater, 2008, 160: 181

[18] Cao M H, Wang B B, Yu H S, Wang L L, Yuan S H, Chen J. J Hazard Mater, 2010, 179: 1143

[19] Qu Y, Zhang C J, Li F, Chen J, Zhou Q. Water Res, 2010, 44: 2939

[20] Panchangam S C, Lin A, Shaik K L, Lin C F. Chemosphere, 2009, 77: 242

[21] Zhao B X, Zhang P Y. Catal Commun, 2009, 10: 1184

[22] Li Z M, Zhang P Y, Shao T, Li X Y. Appl Catal B, 2012, 125: 350

[23] Li X Y, Zhang P Y, Jin L, Shao T, Li Z M, Cao J J. Environ Sci Technol, 2012, 46: 5528.

[24] Dillert R, Bahnemann D, Hidaka H. Chemosphere, 2007, 67: 785

[25] Imoberdorf G, Mohseni M. J Hazard Mater, 2011, 186: 240

[26] Giri R R, Ozaki H, Okada T, Takikita S, Taniguchi S, Takanami R. Water Sci Technol, 2011, 64: 1980

[27] Cheng J, Vecitis C D, Park H, Mader B T, Hoffmann M R. Environ Sci Technol, 2008, 42: 8057

\section{纳米针状氧化镓光催化降解纯水和废水中全氟辛酸}

\author{
郡田，张彭义*，李振民，金玲 \\ 清华大学环境学院环境模拟与污染控制国家重点联合实验室, 北京100084
}

摘要: 采用聚乙烯醇调控的水热法合成了对全氟辛酸(PFOA)有高光催化活性的纳米针状 $\mathrm{Ga}_{2} \mathrm{O}_{3}$. 其颗粒长3-6 $\mu \mathrm{m}$, 宽 100-200 $\mathrm{nm}$, 具有较大的比表面积 $\left(25.95 \mathrm{~m}^{2} / \mathrm{g}\right)$ 和纳米孔结构 (4-25 nm). 在普通紫外光照射下 $(\lambda=254 \mathrm{~nm})$, 纳米针状 $\mathrm{Ga}_{2} \mathrm{O}_{3}$ 光催化降解纯水 中 PFOA的反应半衰期为 $18.2 \mathrm{~min}$, PFOA的一级反应降解动力学常数为 $2.28 \mathrm{~h}^{-1}$, 分别为商品 $\mathrm{Ga}_{2} \mathrm{O}_{3}$ 和 $\mathrm{TiO}_{2}$ 作为催化剂时的 7.5 和 16.8 倍. 此外, 当纳米针状 $\mathrm{Ga}_{2} \mathrm{O}_{3}$ 与真空紫外光 $(\lambda=185 \mathrm{~nm}$ ) 结合时, 不仅可以更高效地降解纯水中的PFOA (反应速率常数 4.03 $\mathrm{h}^{-1}$ ), 而且能有效消除废水中共存有机物的影响, 从而高效分解废水中的PFOA (反应速率常数 $3.51 \mathrm{~h}^{-1}$ ), 且此方法的能耗远远低于 文献报道的其他方法的能耗值.

关键词: 纳米材料; 氧化镓; 全氟辛酸; 光催化; 真空紫外光 
收稿日期: 2013-03-31. 接受日期: 2013-05-06. 出版日期: 2013-08-20.

*通讯联系人. 电话: (010)62796840; 传真: (010)62797760; 电子信箱: zpy@tsinghua.edu.cn

基金来源：国家自然科学基金(21177071, 21221004); 国家重点基础研究发展计划(973计划, 2013CB632403).

本文的英文电子版由Elsevier出版社在ScienceDirect上出版(http://www.sciencedirect.com/science/journal/18722067).

\section{1. 前言}

全氟辛酸( $\left.\mathrm{PFOA}, \mathrm{C}_{7} \mathrm{~F}_{15} \mathrm{COOH}\right)$ 是近年来广受关注的 全氟羧酸化合物(Perfluorocarboxylic acids, PFCAs), C-F 原子的牢固的结合使得PFOA具有很强的化学稳定性和 热稳定性. PFOA的稳定性和疏水疏油性使其广泛应用 于工业品和生活消费品生产领域. 众多研究表明, 全氟 辛酸在全球水域、动物和人体中普遍存在 ${ }^{[1-5]}$, 具有包括 遗传毒性、雄性生殖毒性、神经毒性、发育毒性及内分 泌干扰作用等多种毒性和可能的致癌性 ${ }^{[6-8]}$, 是一种对 全身多器脏具有毒性的环境污染物, 其对环境和人体健 康造成的潜在威胁引发广泛关注.

PFOA主要通过工业生产中氟聚物的加工和使用释 放到环境中 ${ }^{[9]}$, 主要来源于工厂废水排放 ${ }^{[10,11]}$. 由于 PFOA的生物、化学和热稳定性高, 常规的处理方法如生 物降解、氧化还原法均难以使其降解 ${ }^{12]}$, PFOA的降解方 法有高温燃烧法 ${ }^{[13]}$ 、超声热解法 ${ }^{[14,15]}$ 和光化学法 ${ }^{[16-19]}$ 等. 超声热解法需要借助于超声产生的气泡壁处超过 $527^{\circ} \mathrm{C}$ 的高温进行热解反应, 具有电耗大、反应条件苛刻 的缺点; 高温燃烧分解全氟辛酸的同时需要同时焚烧掉 用来吸附的介质, 成本高; 光化学法降解速度慢, 反应时 间长. 光催化法可在温和调解下降解去除有机污染物, 但广为研究的 $\mathrm{TiO}_{2}$ 光催化剂降解全氟羧酸类物质的速 率低 ${ }^{[20]}$. 我们前期研究发现, $\beta-\mathrm{Ga}_{2} \mathrm{O}_{3}$ 和 $\mathrm{In}_{2} \mathrm{O}_{3}$ 光催化降 解全氟羧酸类物质的活性高于 $\mathrm{TiO}_{2}$, 但其催化活性仍有 待提高 ${ }^{[21-23]}$. 本文采用聚乙烯醇(PVA)辅助水热法合成 了纳米针状 $\mathrm{Ga}_{2} \mathrm{O}_{3}$, 其在紫外光下能高效降解纯水和废 水中的PFOA.

\section{2. 实验部分}

\section{1. 催化剂的制备}

取 $2 \mathrm{~g}(5 \mathrm{mmol}) \mathrm{Ga}\left(\mathrm{NO}_{3}\right)_{3} \cdot x \mathrm{H}_{2} \mathrm{O}$ 溶解在 $20 \mathrm{ml}$ 水中, 然 后加入 0.1173 g PVA $\left(M_{\mathrm{W}}=22000\right)$, 用 $\mathrm{NaOH}$ 调节 $\mathrm{pH}$ 至 6.4 , 将溶液在 $90^{\circ} \mathrm{C}$ 下水浴加热 $10 \mathrm{~min}$, 至PVA完全溶解. 将以上溶液转移到 $25 \mathrm{ml}$ 聚四氟乙烯水热釜中, 密封后放 置在恒温干燥箱中, 于 $200{ }^{\circ} \mathrm{C}$ 下保持 $8 \mathrm{~h}$, 然后自然冷却 至室温, 将釜内产物离心分离, 分别用高纯水和无水乙 醇洗3次, 所得白色固体在室温下干燥 $12 \mathrm{~h}$, 干燥后的粉
末置于管式炉中, 在 $\mathrm{N}_{2}$ 中以 $1{ }^{\circ} \mathrm{C} / \mathrm{min}$ 升至 $700{ }^{\circ} \mathrm{C}$, 并在此 温度下保温 $2 \mathrm{~h}$ 后得产物.

\section{2. 催化剂的表征}

利用 X射线衍射仪 (XRD, PANalytical 公司 X'Pert PRO MPD型)分析样品的物相, 管电压为 $40 \mathrm{kV}$, 管电流 为 $200 \mathrm{~mA}$. 采用扫描电镜(SEM, Hitachi公司 S-5500型)、 透视电镜(TEM, JEOL公司JEM 2010F型)观察样品的颗 粒形貌, 加速电压分别为 $5.0 \mathrm{kV}$ 和 $200 \mathrm{kV}$. 采用配置积 分球的紫外-可见分光光度计(岛津公司UV2700型)测试 样品的光吸收特性. 采用比表面积测试仪 (BET, Quantachrome公司AUTOSORB-1MP型)测试样品的 $\mathrm{N}_{2}$ 吸附-脱附等温曲线.

\section{3. 光催化PFOA降解反应}

光催化降解PFOA反应在环管式石英反应器中进行. 分别选用 2 种低压录灯 (14 W, 广州雪莱特公司)为光源: (1)发射 $254 \mathrm{~nm}$ 紫外线的灯, 简称UV灯; (2)发射 $254 \mathrm{~nm}$ 紫外线外, 还能发射少量 $185 \mathrm{~nm}$ 真空紫外线 $(\lambda<200 \mathrm{~nm}$ 的紫外线)的灯, 简称VUV灯, 两者外形和尺寸均一致. 光源置于光反应器的中间, 通过石英套管与反应溶液分 离. 氧气由反应器底部进气口经过篮板均匀分配后进入 到反应溶液, 流量为 $60 \mathrm{ml} / \mathrm{min}$. 反应器外部夹层水套中 通入冷凝水以控制反应在恒定温度 $\left(25^{\circ} \mathrm{C}\right)$ 下进行. 反应 时, 先将 $0.075 \mathrm{~g}$ 光催化剂加入到 $150 \mathrm{ml}$ 的PFOA水溶液 $\left(C_{0} \approx 500 \mu \mathrm{g} / \mathrm{L}\right)$ 中, 搅拌 $1 \mathrm{~h}$ 后, 将混合液移入光反应器, 并通气体 $10 \mathrm{~min}$ 后开紫外灯. 一定时间间隔取样, 用 0.22 $\mu \mathrm{m}$ 滤膜过滤, 滤后样品保存在 $4^{\circ} \mathrm{C}$ 待测.

PFOA及其短链全氟羧酸 $\left(\mathrm{C}_{2}-\mathrm{C}_{7}\right)$ 降解产物采用超高 效液相色谱仪-串联质谱仪(Quatto Premier XE, Waters) 进行鉴别与定量分析. 采用多反应监测(MRM)模式进 行定量分析. 分离柱为Acquity UPLC ${ }^{\circledR}$ Beh C18柱(1.7 $\mu \mathrm{m}, 2.1 \mathrm{~mm}$ i.d. $\times 50 \mathrm{~mm})$, 柱温 $50^{\circ} \mathrm{C}$. 采用配有电导监 测器的离子色谱仪(Dionex ICS2000)分析氟离子, 样品 通过Ionpac ${ }^{\circledR}$ AG11-HC 保护柱 $(4 \times 50 \mathrm{~mm})$ 和 IonPac ${ }^{\circledR}$ AS11-HC column分离柱 $(4 \mathrm{~mm} \times 250 \mathrm{~mm})$ 进行分离, 柱 温 $30{ }^{\circ} \mathrm{C}$. 淋洗液为含 $3.2 \mathrm{mmol} / \mathrm{L} \mathrm{Na} \mathrm{CO}_{3}$ 和 $1 \mathrm{mmol} / \mathrm{L}$ $\mathrm{NaHCO}_{3}$ 的水溶液, 流速为 $1.0 \mathrm{ml} / \mathrm{min}$.

\section{3. 结果与讨论}




\section{1. $\mathrm{Ga}_{2} \mathrm{O}_{3}$ 的晶相}

图1为水热产物经 $700{ }^{\circ} \mathrm{C}$ 加热 $2 \mathrm{~h}$ 后样品的XRD谱. 可以看出, 合成的样品具有良好的结晶度, 为纯的 $\beta-\mathrm{Ga}_{2} \mathrm{O}_{3}$ 晶相 $(a=12.2270, b=3.0389, c=5.8079$, JCPDS 41-1103), 没有发现其它杂质存在.

\section{2. $\mathrm{Ga}_{2} \mathrm{O}_{3}$ 的形貌}

图2为 $\beta-\mathrm{Ga}_{2} \mathrm{O}_{3}$ 样品的SEM照片. 由图可见, 样品为 两端略细的针状物, 其尺寸分布均匀, 分散性较好, 长 3-6 $\mu \mathrm{m}$, 宽100-200 nm, 由于辐烧过程中的脱水收缩, 样 品表面比较粗粮.

$\beta-\mathrm{Ga}_{2} \mathrm{O}_{3}$ 样品高倍SEM照片(见图2(b))和TEM照片 (见图3(a))进一步证实该样品分散性较好, 没有明显的团 聚, 宽100-200 nm, 为两端略细的纳米针状结构. 此外, 点状的选区电子衍射(SAED)照片表明合成的 $\mathrm{Ga}_{2} \mathrm{O}_{3}$ 样 品具有单晶结构, 清晰的衍射斑点表明产物具有良好的 结晶性. 图3(b)为单根纳米棒尖端(插图方框位置)的 HRTEM照片. 可以看到纳米针表面清晰的晶格条纹, 垂 直于纳米针生长方向的晶面间距为 $0.152 \mathrm{~nm}$, 对应 $\beta-\mathrm{Ga}_{2} \mathrm{O}_{3}(020)$ 晶面, 所以制备的 $\beta-\mathrm{Ga}_{2} \mathrm{O}_{3}$ 纳米针长轴方向 与[020]方向平行, 说明 $\beta-\mathrm{Ga}_{2} \mathrm{O}_{3}$ 纳米针沿 [020]方向生长.

\section{3. $\mathrm{Ga}_{2} \mathrm{O}_{3}$ 的比表面积与孔分布}

图4为 $\mathrm{Ga}_{2} \mathrm{O}_{3}$ 样品的 $\mathrm{N}_{2}$ 吸附-脱附等温曲线和孔径分 布. 由图可见, 吸附等温线为IV型, 且带有回滞环, 说明 所得 $\mathrm{Ga}_{2} \mathrm{O}_{3}$ 样品具有介孔. 还可以看出, 样品含有少量 4 $\mathrm{nm}$ 左右以及 6-25 nm的孔. 这些孔可能是由于热处理过 程中 $\mathrm{Ga}_{2} \mathrm{O}_{3}$ 前驱体脱水和催化剂堆积形成的, 使得样品 的比表面积增大为 $25.95 \mathrm{~m}^{2} / \mathrm{g}$, 高于商品 $\mathrm{Ga}_{2} \mathrm{O}_{3}$ 的比表面 积 $\left(11.52 \mathrm{~m}^{2} / \mathrm{g}\right)$.

\section{4. $\mathrm{Ga}_{2} \mathrm{O}_{3}$ 的UV-Vis吸收谱}

图5为纳米针状 $\mathrm{Ga}_{2} \mathrm{O}_{3}$ 和商品 $\mathrm{Ga}_{2} \mathrm{O}_{3}$ 的UV-Vis谱. 由 图可见, 各 $\mathrm{Ga}_{2} \mathrm{O}_{3}$ 样品在200-380 nm内有明显的吸收, 其 中本文所制的 $\mathrm{Ga}_{2} \mathrm{O}_{3}$ 样品的吸收略有蓝移. 这是由于催 化剂尺寸减小而表现出量子尺寸效应所致. 由图5的内 插图 $h v-(a h v)^{2}$ 关系可知, 针状 $\mathrm{Ga}_{2} \mathrm{O}_{3}$ 和商品 $\mathrm{Ga}_{2} \mathrm{O}_{3}$ 的禁带 宽度分别为 4.68 和 $4.57 \mathrm{eV}$.

\subsection{UV光下纯水中PFOA的光催化降解}

图6 为UV光下自制针状 $\mathrm{Ga}_{2} \mathrm{O}_{3}$, 商品 $\mathrm{Ga}_{2} \mathrm{O}_{3}, \mathrm{TiO}_{2}$, (Degussa, P25)和没有光催化剂条件下纯水中PFOA的降 解情况. 纯水中PFOA浓度为 $500 \mu \mathrm{g} / \mathrm{L}$ 时, $\mathrm{pH}$ 值约为 4.8 , 整个反应过程中未调节 $\mathrm{pH}$. 由图可见, 未投加光催化剂 时, 反应 $3 \mathrm{~h}$ 后约有 $3.2 \%$ 的PFOA被分解; 以 $\mathrm{TiO}_{2}$ 为催化 剂时, $3 \mathrm{~h}$ 降解约 $24 \%$; 在商品 $\mathrm{Ga}_{2} \mathrm{O}_{3}$ 催化下, 反应 $3 \mathrm{~h}$ 后
PFOA降解率达到 $38 \%$, 而使用针状 $\mathrm{Ga}_{2} \mathrm{O}_{3}$ 时, 反应 $1 \mathrm{~h}$ 后 PFOA降解到检测限以下, 降解速率大大提高.

在不同催化剂作用下纯水中微量PFOA的降解基本 遵循拟一级反应动力学, 如表1所示, 自制针状 $\mathrm{Ga}_{2} \mathrm{O}_{3}$ 的 反应速率常数为 $2.28 \mathrm{~h}^{-1}$, 分别是商品 $\mathrm{Ga}_{2} \mathrm{O}_{3}$ 和 $\mathrm{TiO}_{2}$ 的 7.5 和16.8倍.

$\mathrm{Ga}_{2} \mathrm{O}_{3}$ 对PFOA降解的高活性可归因于类似于同系 的半导体 $\mathrm{In}_{2} \mathrm{O}_{3}, \mathrm{Ga}_{2} \mathrm{O}_{3}$ 与PFOA也有特异的结合方式, 有 利于光生空穴与 PFOA直接反应 ${ }^{[23]}$. 同时, 纳米针状 $\mathrm{Ga}_{2} \mathrm{O}_{3}$ 具有较大的比表面积和纳米孔结构. 大的比表面 积能够提供更多的吸附和反应活性位, 因而比商品 $\mathrm{Ga}_{2} \mathrm{O}_{3}$ 具有更高的光催化性能.

UPLC-MS/MS 检测结果表明, PFOA降解的主要中 间产物为含 $2-7$ 个碳原子的短链全氟羧酸. 图7是在纳米 针状 $\mathrm{Ga}_{2} \mathrm{O}_{3}$ 光催化剂作用下, 这些短链全氟翔酸产物和 $\mathrm{F}^{-}$浓度随反应时间的变化. 由图可见, 反应开始时, 全氟 庚酸(PFHpA)浓度增长最快, 反应 30 min 即达最大值, 之 后逐渐降低. 在反应30-60 min间, 随着PFHpA浓度快速 降低, 全氟已酸(PFHxA)的浓度快速增长, 60 min达最大 值后降低, 其它的短链羧酸产物浓度在反应 $3 \mathrm{~h}$ 内均随时 间的延长而逐渐增加, 但浓度都很低, 小于 $10 \mu \mathrm{g} / \mathrm{L}$, 且碳 链越短, 浓度水平越低. 由此可见, PFOA的降解是按照 逐级去除 $\mathrm{CF}_{2}$ 单元进行的 ${ }^{[24]}$. 图7还给出了氟离子随反 应时间的变化. 在PFOA降解的同时, 氟离子浓度随反应 时间的增加而不断增加, 在纳米针状 $\mathrm{Ga}_{2} \mathrm{O}_{3}$ 作用下反应3 $\mathrm{h}$ 后, PFOA的脱氟率达到 $58 \%$, 即 $58 \%$ 的有机氟转化为无 机氟离子.

\subsection{VUV光下纯水中PFOA的光催化降解}

VUV光是 $\lambda<200 \mathrm{~nm}$ 的紫外光, 其光子能量更大, 更 易于直接光解部分有机污染物, 或与水反应产生强氧化 性的羟基自由基 $\left(\mathrm{HO}^{\circ}\right)^{[25]}$. 在 $\operatorname{VUV}$ 光 $(\lambda=185 \mathrm{~nm})$ 下, 针 状 $\mathrm{Ga}_{2} \mathrm{O}_{3}$ 、商品 $\mathrm{Ga}_{2} \mathrm{O}_{3}$ 和 $\mathrm{TiO}_{2}$ 催化降解纯水中的PFOA, 反 应结果见图 8. 可以看出, 不加催化剂时, 反应 $3 \mathrm{~h}$ 内, PFOA $(500 \mu \mathrm{g} / \mathrm{L})$ 降解到检测限以下, 说明VUV可高效降 解PFOA; 当它与商品 $\mathrm{Ga}_{2} \mathrm{O}_{3}$ 结合时, PFOA降解速率并 未明显提高; 而与 $\mathrm{TiO}_{2}$ 结合时, 反应 $3 \mathrm{~h}$ 后PFOA的降解 率反而降至 $92 \%$. 这主要是由于县浮的 $\mathrm{TiO}_{2}$ 吸收和散射 了部分VUV光, 减少了溶液对它的吸收, 且 $\mathrm{TiO}_{2}$ 本身光 催化降解PFOA活性不高所致. 当以纳米针状 $\mathrm{Ga}_{2} \mathrm{O}_{3}$ 为 催化剂时, $40 \mathrm{~min}$ 内 PFOA降解到检测限以下, 半衰期为 $10.3 \mathrm{~min}$, 速率常数为 $4.03 \mathrm{~h}^{-1}$, 是UV光下的 1.77 倍. 可见 由于VUV光具有直接光解PFOA的能力, 再加上纳米针 
状 $\mathrm{Ga}_{2} \mathrm{O}_{3}$ 对PFOA有高催化活性, 二者结合能更加高效地 降解PFOA. 纳米针状 $\mathrm{Ga}_{2} \mathrm{O}_{3}$ 降解纯水中PFOA的能耗为 $94.6 \mathrm{~kJ} / \mu \mathrm{mol}$. Vecitis等 ${ }^{[12]}$ 采用超声降解水中微量PFOA 的方法中, 超声降解的半衰期最短为 $15 \mathrm{~min}$ (PFOA浓度 $200 \mathrm{nmol} / \mathrm{L}$ ), 相应的能量消耗为 $1300 \mathrm{~kJ} / \mu \mathrm{mol}$.

\section{7. 针状氧化镓对废水中PFOA的光催化降解}

为考察自制纳米针状 $\mathrm{Ga}_{2} \mathrm{O}_{3}$ 对实际废水中PFOA的 降解效果, 我们以城市污水处理厂生物处理后的出水为 原水(TOC $18.9 \mathrm{mg} / \mathrm{L}$ ) 配制 $500 \mu \mathrm{g} / \mathrm{L}$ 的 PFOA 反应溶液. 为了比较, 溶液 $\mathrm{pH}$ 亦调至4.8. 图9为UV光和VUV光下 针状 $\mathrm{Ga}_{2} \mathrm{O}_{3}$ 和商品 $\mathrm{Ga}_{2} \mathrm{O}_{3}$ 降解废水中PFOA的反应结果. 由图可见, 在UV光下, 以纳米针状 $\mathrm{Ga}_{2} \mathrm{O}_{3}$ 为催化剂反应 $160 \mathrm{~min}$ 后, PFOA才能降到检测限以下, 长于降解纯水 中PFOA的 $60 \mathrm{~min}$, 这是由于废水中其它有机物吸附在 催化剂表面, 占据了活性位所致. 同样地, VUV直接光 解PFOA $3 \mathrm{~h}$ 后废水中PFOA的降解率降为 $92 \%$. 当 VUV 光与商品 $\mathrm{Ga}_{2} \mathrm{O}_{3}$ 结合时, $3 \mathrm{~h}$ 后的降解率仅提高到 $95 \%$; 而与针状 $\mathrm{Ga}_{2} \mathrm{O}_{3}$ 结合时, 65 min后废水中PFOA降解到检 测限以下, 降解效率显著提高. VUV光不仅能部分光解 PFOA, 还能有效分解吸附在催化剂表面的有机物, 使纳 米针状 $\mathrm{Ga}_{2} \mathrm{O}_{3}$ 恢复其降解PFOA的高活性, 相应的一级反
应速率常数为 $3.51 \mathrm{~h}^{-1}$ (半衰期 $11.8 \mathrm{~min}$ ), 远高于文献报 道的降解速率. $\mathrm{Li}$ 等 ${ }^{[23]}$ 以氧化铟和臭氧结合 UV光下催 化降解废水中的PFOA(TOC $18.9 \mathrm{mg} / \mathrm{L}$, PFOA $30 \mathrm{mg} / \mathrm{L}$ ), 反应 $4 \mathrm{~h}$ 降解才达 $80 \%$, Giri等 ${ }^{[26]}$ 以VUV光降解废水中的 PFOA (NPOC $3.5 \mathrm{mg} / \mathrm{L}, \mathrm{PFOA} 2.43 \mu \mathrm{mol} / \mathrm{L}$ ), $3 \mathrm{~h}$ 后降解 率仅 $34 \%$. 此外, 纳米针状 $\mathrm{Ga}_{2} \mathrm{O}_{3}$ 与VUV结合去除废水中 微量PFOA的能耗为 $108.6 \mathrm{~kJ} / \mu \mathrm{mol}$, 而Cheng等 ${ }^{[27]}$ 以超声 法降解废水中的PFOA (TOC $20 \mathrm{mg} / \mathrm{L}$, PFOA $100 \mu \mathrm{g} / \mathrm{L}$ ), 反应速率常数仅为 $1.26 \mathrm{~h}^{-1}$, 能耗高达 $4099 \mathrm{~kJ} / \mu \mathrm{mol}$.

\section{4. 结论}

采用PVA辅助水热法合成了纳米针状 $\mathrm{Ga}_{2} \mathrm{O}_{3}$, 它具 有较大的比表面积和纳米孔结构. 相比于商品 $\mathrm{Ga}_{2} \mathrm{O}_{3}$ 和 $\mathrm{TiO}_{2}$, 该样品对 PFOA表现出很高的光催化降解活性, UV光下其光催化降解纯水中PFOA的反应半衰期为 18.2 $\mathrm{min}$, 一级反应速率常数分别为商品 $\mathrm{Ga}_{2} \mathrm{O}_{3}$ 和 $\mathrm{TiO}_{2}$ 为催化 剂时的7.5和16.8倍. 当该样品为催化剂降解废水中的 PFOA时, 由于其他有机物的存在而降低了光催化降解 PFOA的速率. 纳米针状 $\mathrm{Ga}_{2} \mathrm{O}_{3}$ 和VUV光的结合可发挥 VUV有效降解废水中其它有机物的作用, 从而高效地光 催化降解废水中的PFOA, 其能耗远远低于文献值. 